\title{
Assessment of a cabbage/pak choï crop association to manage aphid and parasitoid populations on cabbage crops in Senegal
}

\author{
Aguibou DIALLO ${ }^{1,2^{*}}$, Dienaba SALL-SY ${ }^{2}$, Dominique BORDAT ${ }^{1}$ and \\ Karamoko DIARRA ${ }^{1}$ \\ ${ }^{1} U C A D, B P$ 7925, Dakar, Sénégal. \\ ${ }^{2}$ ISRA/CDH, BP 3120, Dakar, Sénégal. \\ *Corresponding author; E-mail: aguibounene@hotmail.fr; BP 7925,Dakar, Senegal.
}

\begin{abstract}
In Senegal, vegetable production is an important area within the agricultural sector and contributes to improve the local diet. Damage caused by aphids in particular puts heavy pressure on vegetables production. Crop associations play an important role in controlling insect pests in some countries. The aims of this study include investigations into the diversity of aphid and parasitoid populations, and an evaluation of the effects of crop associations between cabbage and pak choï. The experimental design used is a randomized block with four treatments and two controls, that is cabbage and pak choï , and two crop associations, that is pak choï between cabbage rows, and pak choï around cabbage beds. Two aphid species, Myzus persicae, and Lipaphis pseudobrassicae are identified. The Braconidae Diaeretiella rapae (Mac Intosh) (Hymenoptera: Braconidae) is the only parasitoid met during the study. Myzus persicae (Sulzer) is more abundant than Lipaphis pseudobrassicae (Davis). Myzus persicae and L. pseudobrassicae were not controlled by the cabbage / pak choï associations. Aphids populations decreased during the heading phase of the cabbage. This preliminary study contributes to a better understanding of the potential use of crop associations to manage cabbage aphid populations in Senegal.

(C) 2017 International Formulae Group. All rights reserved.
\end{abstract}

Keywords: Crop associations, Myzus persicae, Lipaphis pseudobrassicae, Diaeretiella rapae, Brassicaceae, Senegal.

\section{INTRODUCTION}

The Brassicaceae has become one of the most widely cultivated crops with more than 37 million hectares grown worldwide (FAOSTAT, 2013). Its production has reached 152 million tons in 2013 (FAOSTAT, 2013). Now, they contribute to more than 26 billion US\$ in the worldwide economy ( FAOSTAT, 2013). Among cultivated species, the cabbage remains a very important crop providing income and nutrition and enabling small farms to remain financially viable (Grzywacz et al., 2010). In West Africa, the head cabbage is grown on 14884 hectares with annual production of 292342 tons (FAOSTAT, 2013). In Senegal, the statistical data in 2012 showed that the head cabbage ranked $5^{\text {th }}$ position after the onion, the tomato, the industrial tomato, the cherry tomato, and the sweet potato accounting for just over $7 \%$ of 
national vegetable production. However, damage caused by insect pests, particularly aphids, is a major obstacle in increasing yields and quality of products (Sarfraz et al., 2005 ; Emden, 2007 ; Diatte et al., 2016 ; Labou et al., 2016). The aphids reproduce quickly and cause some important damages to the host plants (Dedryver, 2007 ; Giordanengo et al., 2010). Additionally, the honeydew produced by aphids and this accumulation on the hostplant leaves contribute to the fungi development as Fumagina which disturb the plant photosynthesis (Giordanengo et al., 2010). The aphids are known to be virus vectors and more than 50 species of aphids are noticed as vectors of virus (Varveri, 2000). In Senegal, few studies have been undertaken on aphid species and their natural enemies. Collingwood et al. (1981) reported the presence of Myzus persicae on Chilli pepper during insecticidal trials in Senegal. In Senegal, a census of aphids was carried out in 2012 and a list of 18 aphid species was established on different host plants, however, a study on aphid auxiliaries was not carried out (Coeur d'Acier, 2012).

Several control methods against these pests are used and principally the chemical control. The high use of insecticides affects the safety of food products but also biodiversity and regulating services of pest insects (natural enemies) (Macharia et al., 2005 ; Gomgnimbou et al., 2009).

Some alternative control methods have been developed among which are the concept of crop associations (Hooks and Johnson, 2003 ; Ponti et al., 2007 ; Bickerton and Hamilton, 2012). The argument more advised is the housing simplification and the single crop farming establishment favour the plots colonization by insect pests (Meehan et al., 2011). Pest management theories considering the trophic levels are behind two hypotheses proposed by Root (1973) to explain the importance of herbivore in monoculture compared with diversified cultures. In a diversified culture where the resources are less concentrated, herbivores found with difficulty their host plant, decreasing in the way their population importance; hypothesis of the resource concentration (Root, 1973). A complex housing favour the natural enemies action; hypothesis of natural enemies (Root, 1973). Beyond the cultural associations, the phenology of the plant can also control pests. The work of Sow et al., 2013 showed that Plutella xylostella populations decreased during the head of the cabbage.

The objectives of this study are : (i) to estimate the aphid and parasitoid populations abundance; (ii) to estimate the crop associations (cabbage head/pack choï ) effects on the aphids and natural enemy species abundance; (iii) to determine the impact of cabbage age on the aphid and parasitoid populations abundance.

\section{MATERIALS AND METHODS \\ Study site}

This study is carried out on open fields between December 2013 and March 2014, in Malika, located in Dakar Niayes (1447'552" $\left.\mathrm{N} 17^{\circ} 19^{\prime} 818^{\prime \prime} \mathrm{W}\right)$ at $189 \mathrm{~m}$ above sea level. This area is characterized by a long dry season from November to June with small variation of temperatures going 15 from $20{ }^{\circ} \mathrm{C}$ and a short rainy season from July to October. During the rainy season, temperature increases until $35{ }^{\circ} \mathrm{C}$. Cumulative precipitations can reach $500 \mathrm{~mm}$ between August and September.

\section{Experimental design}

Two cabbage species were used: the head cabbage (Brassica oleracea L. var. capitata cv. Copenhagen Market) and the pak choï (Brassica rapa L. var. chinensis cv. "Pak choï white). Experiment were arranged in a randomized complete-block design with four treatments:

- Cabbage alone $(\mathrm{CH})$,

- Pak choï alone (PC), 
- Pak choï between cabbage rows (PCER),

- Pak choï around cabbage beds (PCA).

Each treatment was replicated six times. The head cabbage and the pak choï seeds were sown in plastic alveolus and the young plants transplanted 30 days later. Plants were watered early in the morning or in the evening by the farmer. The fertilizer $(10 \mathrm{~N}, 10$ $\mathrm{P}, 20 \mathrm{~K}$ ) was applied according to the grower method. The experimental unit is a square of two side meters. No chemical treatment was applied during this test.

\section{Sampling method}

The weekly sampling started 38 days after the field transplanting. For each plot, five cabbages were randomly selected. To evaluate aphid abundance and associated parasitism, aphids were collected by cutting a piece of leaf on each sampled cabbage. The collected aphids were taken to laboratory where they were counted and identified. The mummies formed on the leaves were isolated individually in pill-boxes to monitor parasitoids emerged.

The identification of aphid adults was carried out using identification keys (Blackman et al., 1994) and sent to CBGP (CIRAD/Montpellier/France) to be confirmed by a specialist.

\section{Statistical analyses}

The data obtained were registered in Excel software and analyzed with the software XLSTAT version1. 1. 2012. Treatment effects on aphid abundance and parasitoid populations were determined by analysis of variance (ANOVA). Post hoc multiple comparisons of mean values were performed using the Newman-Keuls method $(\mathrm{P}<0,05)$ test. All data were transformed to normalize distributions using $\log _{10}(\mathrm{x}+1)$. The relationships between cabbage age, aphid and parasitoid populations was assessed using Pearson correlation.

\section{RESULTS}

Aphid and parasitoid population abundance

During this study, 3185 aphids were sampled in the different treatments. Two aphid species, Myzus persicae (Sulzer) and Lipaphis pseudobrassicae (Davis), (Hemiptera; Aphididae) and one species of parasitoid, Diaeretiella rapae (Mac Intosh) (Hymenoptera: Braconidae), were identified in the laboratory. Myzus persicae was mainly present with $80 \%$, L. pseudobrassicae was less common with only $20 \%$ of sampled aphids (Figure 1). During the observations of the mummies in the laboratory, 274 D. rapae adults have emerged. Diaeretiella rapae species is a small parasitoid $(3 \mathrm{~mm})$ found worldwid numerous aphid species.

Crop association effects on the behavior of the aphid and parasitoid populations

Numbers of $M$. persicae sampled were statistically more important in the PCA association, where on average, 5.5 individuals were harvested. In the other treatments, 4.19, 3.94 and 3.39 individuals respectively have been harvested in the control $\mathrm{CH}$, in the association PCER and in the control PC (F = 4.417; ddl $=3 ; \mathrm{p}=0.004$ ) (Table 1). However, the number of L. pseudobrassicae individuals harvested was not significant with treatments $(\mathrm{F}=1.285 ; \mathrm{ddl}=3 ; \mathrm{p}=0.279)$ (Table 1$)$. For $D$. rapae adults, there are no significant differences between the treatments and the emerged adult numbers $(\mathrm{F}=2.420 ; \mathrm{ddl}=3 ; \mathrm{p}$ $=0.065)$ (Table 1).

\section{Cabbage age effects on the Aphid populations \\ There was a significant negative correlation between the $M$. persicae populations and cabbage age $(\mathrm{r}=-0.251 ; \mathrm{p}<$ $0.0001)$. The $M$. persicae population increased between the first and the second weeks observation, however a population decrease was noticed in the third observation,}


simultaneous with the beginning of cabbage head formation ( $52^{\text {th }}$ day after transplanting) (Figure 2).

The correlation between the $L$. pseudobrassicae population and cabbage age was significantly negative $(\mathrm{r}=-0.275 ; \mathrm{p}<$ 0.0001). Like the M. persicae population, the L. pseudobrassicae population decreased during the observation period particularly in the third week of observation, simultaneous with the beginning of cabbage head formation ( $52^{\text {th }}$ days after transplanting) (Figure 2).

\section{Cabbage age effects on parasitoid populations}

There was a significant correlation between $D$. rapae populations and cabbage age $(r=0.286 ; p<0.0001)$. The parasitoid appeared in the third observation week, simultaneous with the beginning of the cabbage head formation ( $52^{\text {th }}$ day after transplanting) (Figure 3). Diaeretiella rapae parasitism was zero during the two first observations. The number of aphids parasitized by $D$. rapae is highest in the third week followed by a weak increase of aphids parasitized by $D$. rapae.

Table 1: Comparison of aphid and parasitoid populations according to treatments.

\begin{tabular}{lccc}
\hline Treatments & M. persicae & L. pseudobrassicae & D. rapae \\
\hline PCA & $5.50^{\mathrm{a}}$ & $1.20^{\mathrm{a}}$ & $0.46^{\mathrm{a}}$ \\
PCER & $3.94^{\mathrm{b}}$ & $1.01^{\mathrm{a}}$ & $0.51^{\mathrm{a}}$ \\
CH & $4.19^{\mathrm{b}}$ & $0.78^{\mathrm{a}}$ & $0.59^{\mathrm{a}}$ \\
PC & $3.39^{\mathrm{b}}$ & $1.23^{\mathrm{a}}$ & $0.27^{\mathrm{a}}$ \\
\hline
\end{tabular}

Vertical averages with the same letter are not significantly different (Newman Keuls test 5\%).

The data were transformed by $\log (\mathrm{x}+1)$.

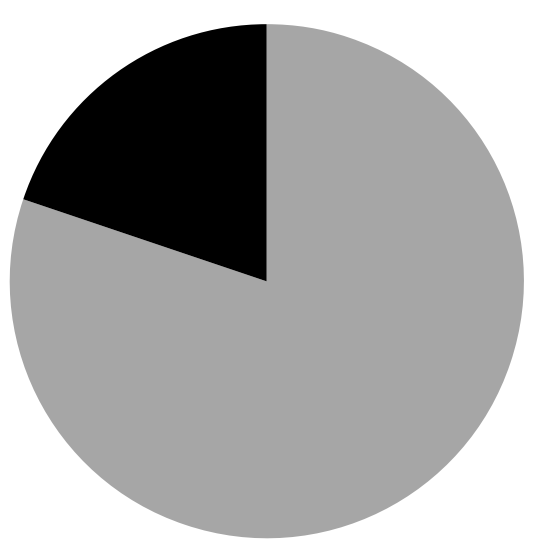

Myzus persicae

- Lipaphis pseudobrassicae

Figure 1: Abundance (\%) of aphid populations sampled in Malika (Dakar). 


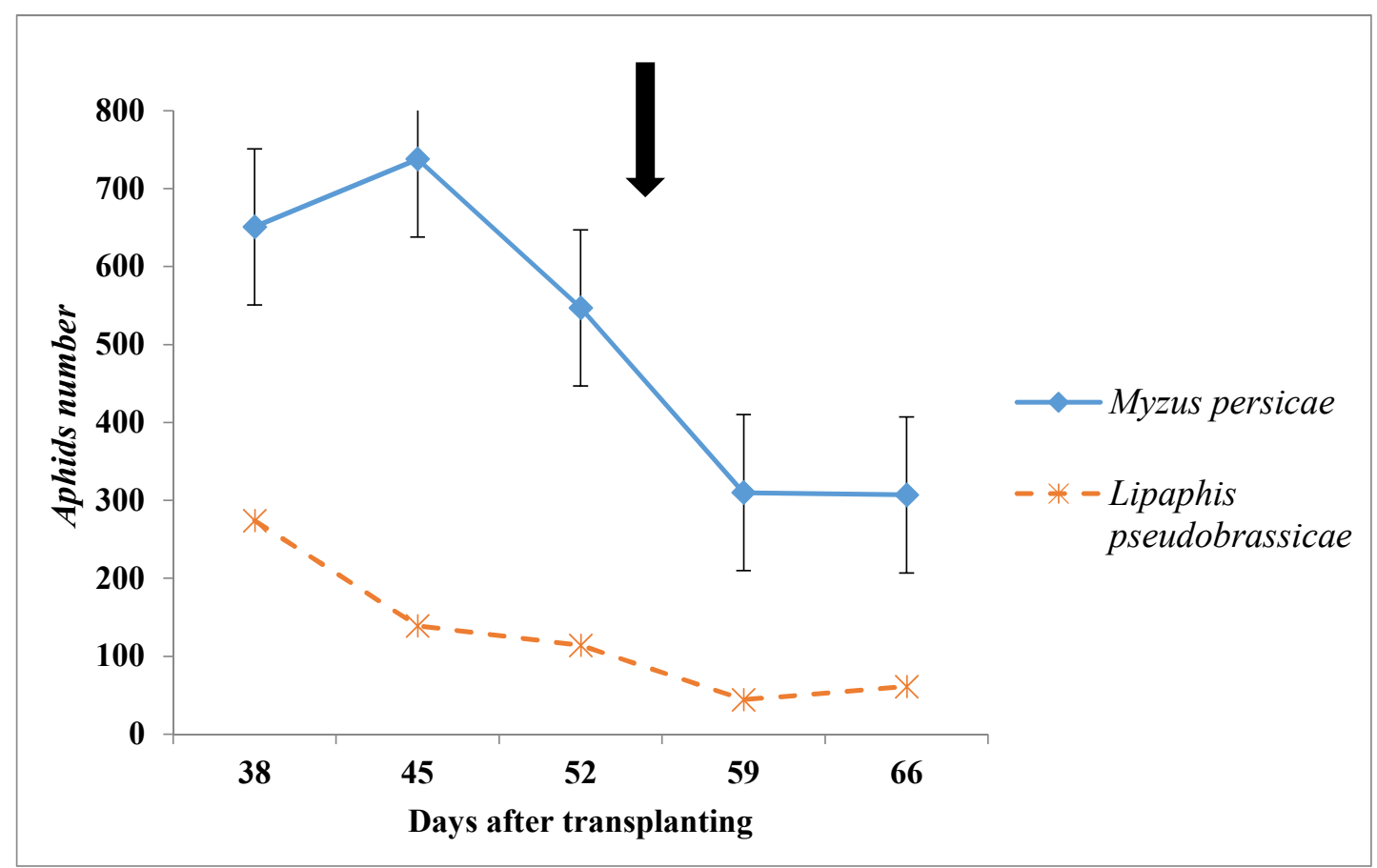

Figure 2: Development of aphid populations according to cabbage age. The black arrow shows start of cabbage head formation.

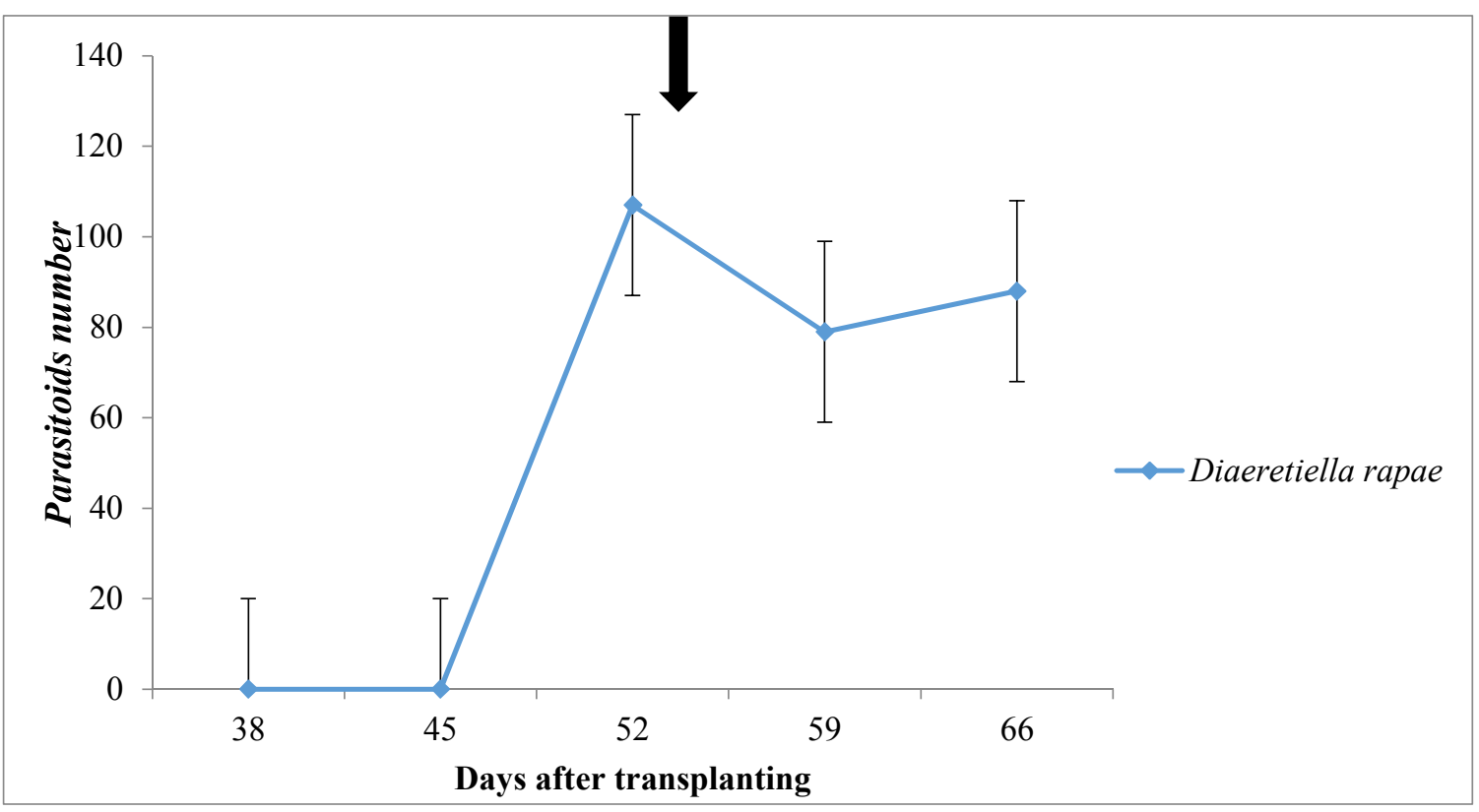

Figure 3: Development of parasitoid populations according to cabbage age. The black arrow shows start of cabbage head formation. 


\section{DISCUSSION}

This study has allowed to identify two aphid species and one Braconid species. The $M$. persicae species is more common than $L$. pseudobrassicae (20\%). This dominance can be explained by the inherent characters of each aphid species. Myzus persicae is a very widespread generalist species which attacks several host plants unlike L. pseudobrassicae a Brassicaceae specialist (Emden, 2007). The large number of $M$. persicae can be explained by the presence of a tomato crop near the cabbage cultures. This tomato crop would have kept $M$. persicae populations at a high level.

In fact, when the two aphid species are reared alone, their fecundity is greater than when they are reared together on the same host plant (Hu et al., 2003). Hu et al. (2003) have shown that $M$. persicae has a higher longevity and fecundity than Lipaphis erysimi (Kaltenbach) when they coexist on the same plant. These results are similar to ours which show the relative importance of $M$. persicae in relation to L. pseudobrassicae.

Our crop associations have not reduced the $M$. persicae and L. pseudobrassicae infestations. The lack of aphids control by the head cabbage / pak choï associations can be explained by the affiliation of these species to the same botanical family. According to Root (1973), the concentration of resource in a favourable habitat favours pest development. Our crop associations can be considered as a similar resource for the two aphid species which explains the level of attack in the associate plots with head cabbage and pak choï. However, in Asia, the pak choï is used with a lot of success as trap plant to control Diamondback moth, a major Lepidopteran pest on cabbage crops (Talekar et al., 1990). Our results are similar to those of Bosquée et al. (2014), where the crop associations have been more attacked by aphids than the controls. However, the results of some authors have shown that the association with plants from different botanical families increase the aphid infestation (Sarker et al., 2007 ; Bickerton and Hamilton, 2012 ; Chevalier Mendes Lopes et al., 2014).

The number of aphids parasitized by $D$. rapae is more important in cabbage control plots and in crop associations plots than in pak choi plots. This can be explained by the importance of the aphid populations in the cabbage controls and in the crop association. Diaeretiella rapae has a large affinity with Brassicaceae plants and parasitizes aphids connected with them, when aphids increase $D$. rapae females easily find host to attack (Ponti et al., 2007 ; Starỳ et al., 2007).

The $M$. persicae and $L$. pseudobrassicae populations were more important before head cabbage formation started. This could be explained by the feeding mode of the aphids which is a phloem diet and therefore the quality of the sap influences their feeding behavior (Dinant et al., 2010).

The correlation between cabbage age and $D$. rapae populations is positive, maximum parasitoid attack was in the third observation periods. Natural enemy populations depend on the host populations (Elliott et al., 2002). Aphid populations abundance during the first two observation weeks leads to a honeydew increase by aphids. This honeydew rich in sugar and in amino acid makes up a dietary source for numerous natural enemies but acts also as a volatile kairomone (Leroy et al., 2009). The volatile compounds from honeydew guide natural enemies towards a diet source, composed of preys or hosts, and increases behaviour such as search, localization and attacks (Leroy et al., 2009). The D. rapae populations decrease in the $4^{\text {th }}$ observation week, and increase weakly in the last week, a result that can be explained by the aphid and the honeydew quality. Honeydew establishes 
a vital diet source for numerous natural enemies, especially D. rapae (Hogervorst et al., 2007).

\section{COMPETING INTERESTS}

We declare that there is no competing interest between the authors. The order of the authors at the level of the article and the content of the document has been validated unanimously.

\section{AUTHORS ' CONTRIBUTIONS}

$\mathrm{AD}$ is the lead investigator; DS-S and DB co-supervised the works and participated in the drafting of the manuscript; $\mathrm{KD}$ is the initiator of the project. He has defined the protocols and coordinated all activities.

\section{ACKNOWLEDGEMENTS}

Many thanks to Dr. A. A. Kirk, entomologist from EBCL/ USDA-ARS for checking the manuscript English. Many thanks too for A. Cœur d'Acier, Aphididae worldwide spécialist and G. Delvare, taxonomist, hymenopteran specialist from the "Centre de Biologie pour la Gestion des Populations (CBGP) de Montpellier", for the insect identifications. We thank the farmers for access to their fields sampling.

\section{REFERENCES}

Akantetou P, Koba K, Nenonene A, Poutouli W, Raynaud C, Sanda K. 2012. Evaluation du potentiel insecticide de l'huile essentielle de Ocimum canum Sims sur Aphis gossypii Glover (Homoptera : Aphididae) au Togo. Int. J. Biol. Chem. Sci., 5 : 1491-1500. DOI: http://dx.doi.org/10.4314/ijbcs.v5i4.15

Bickerton MW, Hamilton GC. 2012. Effects of intercropping with flowering plants on predation of Ostrinia nubilalis (Lepidoptera: Crambidae) eggs by generalist predators in bell peppers.
Environ. Entomol., 41: 612-620. DOI: https://doi.org/10.1603/EN11249

Blackman RL, Eastop VF. 1994. Aphids on the world's trees: an identification and information guide. (Cab International). DOI: https:/www.cabdirect.org/ cabdirect/abstract/19941105799

Bosquée E, Chevalier Mendes Lopes T, Serteyn L, Chen JL, Yong L, Francis F. 2014. Impacts d'une association culturale de pois et de pommes de terre sur les pucerons et auxiliaires aphidiphages en Chine. Entomol. Faun. Faun. Entomol., 67: 97-104. DOI: http://hdl.handle.net/2268/171726

Chevalier Mendes Lopes T, Bodson B, Francis F. 2013. Crop association to improve biological control: case study on pea and wheat aphids. Ecology of Aphidophaga, 12: 23p. DOI: http://hdl.handle.net/2268/157255

Chevalier Mendes Lopes $\mathrm{T}$, Bosquée $\mathrm{E}$, Honba D, Serteyn L, Chen J, Yong L, Francis F. 2014. Effets de deux associations culturales avec du blé sur les populations de pucerons (Homoptera: Aphididae) et d'auxiliaires aphidiphages: étude préliminaire menée en Chine. Entomol. Faun. Faun. Entomol., 67: 113-118. DOI: http:/hdl.handle.net/ 2268/171725

Coeur d'Acier A. 2012. Les pucerons (Homoptera, Aphididae) du Sénégal 1er Partie: bibliographie, répartition et biologie. Bull. IFAN Ch. A. Diop Dakar, 1: $35-54$.

Collingwood EF, Bordouxhe L, Diouf M. 1981. Plant protection. Report on insecticide trials 1980-1981. Synthesis of results 1976-1981. Plant Prot. Rep. Insectic. Trials 1980-1981 Synth. Results., 1976-1981. https://www.cabdirect.org/cabdirect/abst ract/19820594536 
Dedryver C A. 2007. Pucerons : des dégâts et des hommes. Biofutur., 279 : 22-25. DOI: http://cat.inist.fr/?aModele=affiche N\&cpsidt $=18869981$

Diatte M, Brévault T, Sall-Sy D, Diarra K. 2016. Des pratiques culturales influent sur les attaques de deux ravageurs de la tomate dans les Niayes au Sénégal. Int. J. Biol. Chem. Sci., 10 : 681-693. DOI: http://dx.doi.org/10.4314/ijbcs.v10i2.19

Dinant S, Bonnemain JL, Girousse C, Kehr J. 2010. Phloem sap intricacy and interplay with aphid feeding. C. R. Biol., 333: 504-515. DOI:http://doi.org/10.1016/ j.crvi.2010.03.008

Elliott NC, Kieckhefer RW, Michels GJ, Giles KL. 2002. Predator abundance in alfalfa fields in relation to aphids, within-field vegetation, and landscape matrix. Environ. Entomol., 31: 253-260. DOI: http://dx.doi.org/10.1603/0046-225X31.2.253

Emden HFV. 2007. Aphids as Crop Pests, Helmut FvE, Harrington R (eds). CABI: Oxfs, UK.

FAO. 2013. Food and Agriculture Organisation, United Nation. http://www.fao.org/faostat/fr/\#data/GT

Giordanengo P, Brunissen L, Rusterucci C, Vincent C, Van Bel A, Dinant S, Girousse C, Faucher M, Bonnemain JL. 2010. Compatible plant-aphid interactions: how aphids manipulate plant responses. C. R. Biol., 333: 516523. DOI: http://doi.org/10.1016/ j.crvi.2010.03.007

Gomgnimbou AP, Savadogo PW, Nianogo AJ, Millogo Rasolodimby J. 2009. Usage des intrants chimiques dans un agrosystème tropical: diagnostic du risque de pollution environnementale dans la région cotonnière de l'est du Burkina Faso. Biotech, Agro, Soc et Env., 13(4): 499-507. DOI: http://search.proquest.com/openview/d33 9bfb612174f767a9fbbcedc117eb1/1?pqorigsite $=$ gscholar\&cbl $=54738$

Grzywacz D, Rossbach A, Rauf A, Russell D A, Srinivasan R, Shelton AM. 2010. Current control methods for diamondback moth and other brassica insect pests and the prospects for improved management with lepidopteran-resistant $\mathrm{Bt}$ vegetable brassicas in Asia and Africa. Crop Prot., 29: 68-79. DOI: http://doi.org/10.1016/j.cropro.2009.08.0 09

Hogervorst PA, Wäckers FL, Romeis J. 2007. Effects of honeydew sugar composition on the longevity of Aphidius ervi. Entomol. Exp. Appl,. 122: 223-232. DOI: $\quad$ DOI: $\quad 10.1111 / \mathrm{j} .1570-$ 7458.2006.00505.x

Hooks CR, Johnson MW. 2003. Impact of agricultural diversification on the insect community of cruciferous crops. Crop Prot., 22: 223-238. DOI: http://doi.org/10.1016/S0261 2194(02) 00172-2

Hu L, Liu Y, Xu H, Zhi L. 2003. Intra-and interspecific relationship of myzus persicae (sulzer) and lipaphis erysimi (kaltenbacn) on cabbage. Entomol. J. East China., 3: 77-80. DOI: http://europepmc.org/abstract/cba/18980 3

Labou B, Bordat D, Brevault T, Diarra K. 2016. Importance de la" Teigne du chou" dans les Niayes au Sénégal: interrelations avec la température et les cultivars utilisés. Int. J. Biol. Chem. Sci., 10: 706-721. DOI: http://dx.doi.org/10.4314/ijbcs.v10i2.21

Leroy P, Capella Q, Haubruge É. 2009. L'impact du miellat de puceron au niveau des relations tritrophiques entre les plantes-hôtes, les insectes ravageurs et leurs ennemis naturels. Biot. Agro. Soci Envi., 13: 325-334. DOI: 
http://www.pressesagro.be/base/index.ph $\mathrm{p} / \mathrm{base} /$ article/view/402

Macharia I, Löhr B, De Groote H. 2005. Assessing the potential impact of biological control of Plutella xylostella (diamondback moth) in cabbage production in Kenya. Crop Prot., 24: 981-989. DOI: http://popups.ulg.ac.be/ 1780-4507/index.php?id=4171

Meehan TD, Werling BP, Landis DA, Gratton C. 2011. Agricultural landscape simplification and insecticide use in the Midwestern United States. Proc. Natl. Acad. Sci., 108: 11500-11505. DOI: http://dx.doi.org/www.pnas.org/lookup/s uppl/doi:10.1073/pnas.1100751108/-

Mondédji AD, Kasseney BD, Nyamador WS, Abbey GA, Amévoin K, Ketoh GK, Glitho IA. 2016. Effets d'extrait hydroéthanolique de feuilles de neem (Azadirachta indica A. Juss) sur Plutella xylostella (Lepidoptera: Plutellidae) et Lipaphis erysimi (Hemiptera: Aphididae) dans la production du chou au Sud du Togo. Int. J. Biol. Chem. Sci., 10: 1666-1677. DOI: http://dx.doi.org/ 10.4314/ijbcs.v10i4.18

Ponti L, Altieri MA, Gutierrez AP. 2007. Effects of crop diversification levels and fertilization regimes on abundance of Brevicoryne brassicae (L.) and its parasitization by Diaeretiella rapae (M'Intosh) in broccoli. Agric. For. Entomol., 9: 209-214. DOI: http://dx.doi.org/10.1111/j.14619563.2007.00330.x

Robert Y, Bourdin D. 2001. Aphid transmission of potato viruses. In Virus and Virus-like Diseases of Potatoes and Production of Seed-Potatoes. Springer., 195-225. DOI: http://dx.doi.org/ 10.1007/978-94-007-0842-6_20

Root RB. 1973. Organization of a plantarthropod association in simple and diverse habitats: the fauna of collards (Brassica oleracea). Ecol. Monogr., 43: 95-124. DOI: http://dx.doi.org/ $10.2307 / 1942161$

Sarfraz M, Keddie AB, Dosdall LM. 2005. Biological control of the diamondback moth, Plutella xylostella: A review Published online 20 July 2005. Biocontrol Sci. Technol., 15: 763-789. DOI: $\quad$ http://dx.doi.org/10.1080/ 09583150500136956

Sarker PK, Rahman MM, Das BC. 2007. Effect of intercropping with mustard with onion and garlic on aphid population and yield. J. Bio-Sci., 15: 3540. DOI: http://dx.doi.org/10.3329/ jbs.v15i0.2200

Sow G, Diarra K, Arvanitakis L, Bordat D. 2013. The relationship between the diamondback moth, climatic factors, cabbage crops and natural enemies in a tropical area. Folia Hortic., 25: 3-12. DOI: https://doi.org/10.2478/fhort-20130001

Starỳ P, Sampaio MV, Bueno VHP. 2007. Aphid parasitoids (Hymenoptera, Braconidae, Aphidiinae) and their associations related to biological control in Brazil. Rev. Bras. Entomol., 51: 107118. DOI: http://dx.doi.org/10.1590/ S0085-56262007000100018

Talekar NS, Yang JC, Lee ST. 1990. Control of Major Inesct Pests of Cruciferous Vegetables in Taiwan. In Improvement of Production and Marketing for High Quality Vegetables. Proceedings of a Symposium. 139-155. DOI: http://203.64.245.61/fulltext_pdf/EAM/1 900-1990/eam0212.pdf

Varveri C. 2000. Potato Y potyvirus detection by immunological and molecular techniques in plants and aphids. Phytoparasitica, 28: 141-148. DOI: 10.1007/BF02981743. 